\title{
Floral Behavior, Fruit Characteristics and Oil Quality of Some Olive Cultivars "Oleaeuropaea L."
}

\author{
Zienab. F.R. Ahmed", Eman M. A. Taha**, Naglaa, A. A. Abd-Elkarim ${ }^{* * *}$ \\ "Department of Horticulture, Faculty of Agriculture, South Valley University, Qena, \\ Egypt. \\ ${ }^{* *}$ Department of Food Science and Technology, Faculty of Agriculture, South Valley \\ University, Qena, Egypt.
}

\begin{abstract}
$\mathbf{O}$ LIVE consumption is increased around the world due to the organoleptic characteristics and medicinal values of its fruit and oil. To meet this demand, increasing the cultivated area of olive becomes essential in areas rather than the Mediterranean basin. In this respect, some olive cultivars (cvs.) 'Koroneiki', 'Dolci', 'Carotina' and 'Maraki' were cultivatedat the Research Center of South Valley University, Qena. The objective of this study was to monitorand evaluate these cultivars' adaptation under Qena environmental conditions. The flowering behavior, fruit set, fruit growth, and the oil qualityof these four cultivars were assessed for two seasons (2016-2017). The results showed that the growth season began two weeks earlier than usual for all cultivars. 'Koroneiki' cv. had highest number of panicles per shoot but lowest number of flowers per panicle compared to the other cultivars.Despite that, the initial fruit set was high in all cultivars, fruit retention was varied. 'Koroneiki' had higher number of fruit per shoot followed by 'Dolci', 'Maraki' and 'Carotina'. The fruit weight and size were slightly lower than the typical known for all cultivars grown in other regions. 'Maraki' cv. had the highest percentage of oil followed by 'Carotina', 'Koroneiki' and then 'Dolci'. The quality indexes of the oil were within the limits of the stander extra version olive oil for all studied cultivars. Our results revealedthat, each olive cultivar had regular morphological characteristics, fruit propertiesandoilquality, suggesting that these cultivars were able to adaptQena'senvironmental conditions and gave high quality virgin oil.
\end{abstract}

Keywords: Flowering, Inflorescence, Panicle structure, Quality indexes, Fatty acids.

\section{Introduction}

Olive is belongs to the Oleaceae family and has been cultivated in the Mediterranean region for centuries. The fruit and oil production of olive tree have an important role in the economy of many countries around the world. Olive is a drought tolerant tree, therefore, it is growing very well in many arid and semiarid areas(Martin et al., 2005).

Production of olive fruit and oil quality depend on various factors such as cultivar genetic, agricultural practices as well as seasonal environmental factors that mainly affect the physiological behavior of the tree (Cimato, 1990, Martin et al., 2005). Blooming in olive usually begins during the second half of March and variesamong cultivars. Flower bud differentiation and induction depends on the environmental conditions, hormonal balance and tree nutrition, while flower bud opening relays on the region's chilling units (Fabbri and Benelli, 2000). Flower inflorescences (panicles) are mostly born on previous year shoot or 2-3 year old shoots (Lavee et al., 2002). The panicle structure, length and flower number are varying from cultivars to cultivar, from tree to tree, and from shoot to shoot (Lavee et al., 2002 and Seifi et al., 2008). Panicle length is ranged from $3-8 \mathrm{~cm}$ and has between 15- 30 flower (Martin et al., 2005).

Compatibility is an important aspect in olive, as some cultivars are self-compatible orpartiallycompatible and others are self-incompatible and require cross-pollination for optimum fruit set (Connor and Fereres, 2005). Previous reports showed inconsistent results about compatibility

Corresponding author: Zienab F. R. Ahmed, e-mail:zinabriad@yahoo.com, Tel. 01069476428

DOI: 10.21608/ejoh.2019.11082.1103

(C)2019 National Information and Documentation Centre (NIDOC) 
of olive cultivars due to different environmental conditions and insufficient chilling units of the regions (Lavee et al., 2002, Martin et al., 2005, Mookerjee et al., 2005, El-Said et al., 2006). Despite that, olive tree produces thousands of flowers, only 1-2\% set to give a commercial yield (Martin et al., 2005). In most olive cultivars, one flower per panicle is set into fruit and the rest are falling, also number of fruit per shoot decreased 25 days after full bloom due to competition (Rosati et al., 2010). High temperature during fruit growthcausing stress that slowed down some critical functions and led to fruit shriveling and fruit size reduction (Lombardo et al., 2008).

Olive oil is considered as one of the major components of the Mediterranean diet. Recently, its consumption has also spread remarkably outside the Mediterranean basin due to its superior organoleptic characteristics and potential health benefits compared to other vegetable oils (Bertrand, 2002). As a result of this demand, olive cultivation area needs to be increased in the Mediterranean region and elsewhere in the world. The introduction of different olive cultivars to new agro-ecosystems may result in several effects on the tree growth, production, and oil quality (Tous and Romero, 1994, Weiying et al., 1998). For example, hot and dry summer with intense solar radiation substantially increased the oil content in the fruit and change the fatty acids composition (Pannelli et al., 1994)while stability of the oil, fatty acid profile and other quality indexes were not affected (Di Vaio et al., 2012, Tognetti et al., 2007).

Egypt is known to be one of the most important Mediterranean countries in the production of table olives and olive oil. In 2017, Egypt production of olives was roughly 580 thousand tons, more than $18 \%$ of global volumes, it also contributed by about $21 \%$ of the produced olive oil according to the Ministry of Agriculture and Land Reclamation. The area of olive production in Southern Egypt region is about 1\%of the total olive area in Egypt, this area is expected to be increased in the upcoming years. In this respect, this study was conducted to evaluate the flowering behavior, inflorescence structure, fruit characteristics as well as the oil physiochemical and antioxidant properties of some olive cultivars when cultivated under Qena Governorate conditions.

\section{Materials and Methods}

The experiments of this study were carried out during 2016, 2017 seasons at the research center of Horticulture Department, South Valley University, Qena, Egypt. This site is at a latitude of 26.1551 and longitude of 32.716, North 26 9'18', East 32 42'58'. The experimental design Egypt. J. Hort. Vol. 46, No.1 (2019) was randomized complete blocks. Trees were drip- irrigated and received the common culture practices and fertilization. Five of 7 years old trees from each olive cultivar: 'Koroneiki', 'Dolci', 'Carotina' and 'Maraki'were randomly selected from the same orchard for the following measurements:

\section{Flowering}

Flowering initial date of flowering budsappearance, flower opening, fruit set, fruit color change, andtheharvestdate,were recorded for each cultivar during seasons 2016-2017. Inflorescence structure, as number of branches, number of flower per branch, and total number of flower on an inflorescence, was recorded according to (Seifi et al., 2008). Characteristics of 20 flowering shoot (one year old) per tree were determined. The shoot length, total number of buds, number of flower buds, number of inflorescences per shoot and the distribution of flower buds on such shoot was also determined. Effect of the inflorescence distribution on the shoot (Tip, mid, base) on inflorescence length and flower number per inflorescence was recorded. Fifty panicles from each tree were taken to determine their characteristics, length, flowers number, perfect flower percent, initial fruit set percentage and initial fruit number. Twenty shoots per tree were used to record the initial fruit number and the final fruit number as well as the dropped fruit number.

\section{Fruiting}

After harvest, random sample of 50 fruits per tree from each cultivar was collected to determine the following characters: weight, length, width as well as fruit stone and flesh weight. Fruits were dried in the oven at $105^{\circ} \mathrm{C}$ for 48 hrsto determine fruit moisture percentage, and the oil content based on the fruit dry weight by Soxhelt (A.O.A.C, 2000).

\section{Oil quality}

Sample of $5 \mathrm{~kg}$ fruitper tree was picked from each cultivar for oil extraction. The oil was cold extracted mechanically as follows:

Fruits were crushed using grinder mill. The paste was mixed with warm water, subjected to centrifugation, and the oil was collected according to a method of the International Olive Council (I.O.C, 2013). Physiochemical and antioxidant parameters of all cultivars' oil such as: acidity, chlorophyll, Iodine, saponification and cox values, and spectrophotometric indices, phenolic composition, and fatty acid profile were measured (Christie, 1982). The control sample was a commercial extra versionolive oil from the local market. 


\section{Statistical analysis}

The differences between cultivars mean values within a season were analyzed by analysis of variance "ANOVA" at probability level of $5 \%$ (P $\leq 0.05)$ followed by Least Significant Difference Test "LSD" using PROC GLM procedure of Statistical Analysis System (SAS) version 9.2 for Windows, SAS Institute Inc., Cary, NC, USA (SAS $\left.{ }^{2}, 2009\right)$.

\section{Results and Discussion}

Egypt is one of the Mediterranean regions where olive is a common crop cultivated for table and oil extraction. Several cultivars (local and imported) are well grown and had commercial production under environmental conditions of northern region of Egypt. The production area of olive is planned to be extended to the southern region. In this study, adaptation of some olive cultivars under Qena Governorate was evaluated.

\section{Flowering and fruiting duration}

The blooming dates were varied for all studied cultivars, however, flower buds appeared in the last 10 days of February in both seasons. The flowers opening date was in the first half of March in 'Koroneiki' and 'Maraki', while 'Carotina' and 'Dolci' flowers opened in the second half of March ( Table 1 and Fig.1). The full bloom and beginning of fruit set was in the last week of March for most cultivars except for 'Carotina' that wasin the end of March. The duration of blooming ranged between 25-35 days. 'Koroneiki' and 'Dolci' tended to have shorter period 25 days followed by 'Carotina' 30 days while 'Maraki' exhibited longer period 35 days (Table 1 and Fig.1). By the end of blooming, some fruit appeared in the first week of April in all cultivars. Fruits grew and began to change their color to purple by August 10 in 'Dolci' and 10 days later in 'Koroneiki' and 'Carotina' while 'Maraki' fruits were the latest in color change that was in October 25. Harvest date was determined for each cultivar depends on the maturation of the fruit, and was different for each cultivar as it was in September 13 in 'Dolci' an d'Carotina'cvs., while'Koroneiki'was harvested in October 5and 'Maraki' the latest cultivar was harvested in November 21 (Table 1 and Fig.1).

TABLE 1. Initial dates of flowering and fruit growth for some olive cultivars during seasons 2016-2017 .

\begin{tabular}{|c|c|c|c|c|c|c|}
\hline Cultivar & $\begin{array}{l}\text { Floral bud } \\
\text { appearance }\end{array}$ & Flowering & Fruit set & $\begin{array}{c}\text { Fruit } \\
\text { growth }\end{array}$ & $\begin{array}{c}\text { Fruit color } \\
\text { Change }\end{array}$ & Harvest \\
\hline & \multicolumn{6}{|c|}{ Season 2016} \\
\hline Dolci & $25-\mathrm{Feb}$ & 18-Mar & 23-Mar & 23-Mar & 10-Aug & 13- Sep \\
\hline Carotina & 26- Feb & 18- Mar & 28-Mar & 28-Mar & 20-Aug & 13-Sep \\
\hline Koroneiki & 26- Feb & 13- Mar & 25-Mar & 25-Mar & 20-Aug & 5- Oct \\
\hline \multirow[t]{2}{*}{ Maraki } & 20- Feb & 13-Mar & 23-Mar & 23-Mar & 25-Oct & 21-Nov \\
\hline & \multicolumn{6}{|c|}{ Season 2017} \\
\hline Dolci & 27-Feb & 15-Mar & 21-Mar & 21-Mar & 10-Aug & 13-Sep \\
\hline Carotina & 26- Feb & 15-Mar & 26- Mar & 28-Mar & 20-Aug & 13-Sep \\
\hline Koroneiki & 25-Feb & 11- Mar & 21-Mar & 21-Mar & 20-Aug & 5- Oct \\
\hline Maraki & 22- Feb & 11- Mar & 21-Mar & 21-Mar & 25-Oct & 21- Nov \\
\hline
\end{tabular}

As consistent to previous reports blooming/ fruiting date and period was varied from cultivar to cultivar as a response to different environmental conditions and differed topography of different region (Orlandi et al., 2005, El-Said et al., 2006,Pérez López et al., 2008, Saad El-Din et al., 2010).

\section{Floral behavior}

The inflorescences are mostly born on shoots developed in the previous season and barely seen on older shoot. The characteristics of one year old shoot for season 2016-2017 were presented in Table 2. The shoot length ranged between $27.2-36.2 \mathrm{~cm}$, the shortest was 'Koroneiki' shoot while the longest was 'Carotina' while the other cultivars' shoots length was $30.3 \mathrm{~cm}$. The total number of buds ranged between 14- 24.2, 'Carotina' shoot had the lowest number (14 and 15.2 buds) while 'Maraki' had the highest number of buds (23.7 and 24.2) in both seasons respectively. The number of flower buds per shoot in 'Dolci'and 'Koroneiki' shoot was high (11.1, 12.3) compared to 'Maraki' and 'Carotina' shoot that had only about (9.5) flower buds/ shoot. 'Koroneiki' shoot had higher number of buds with two double inflorescences (9.3) that reflect the highest number of inflorescences per shoot (20.2) compared to the other cultivars (Table 2). The flower bud induction and differentiation in olive depends on many factors such as environmental conditions, tree nutrition status and hormonal balance. 


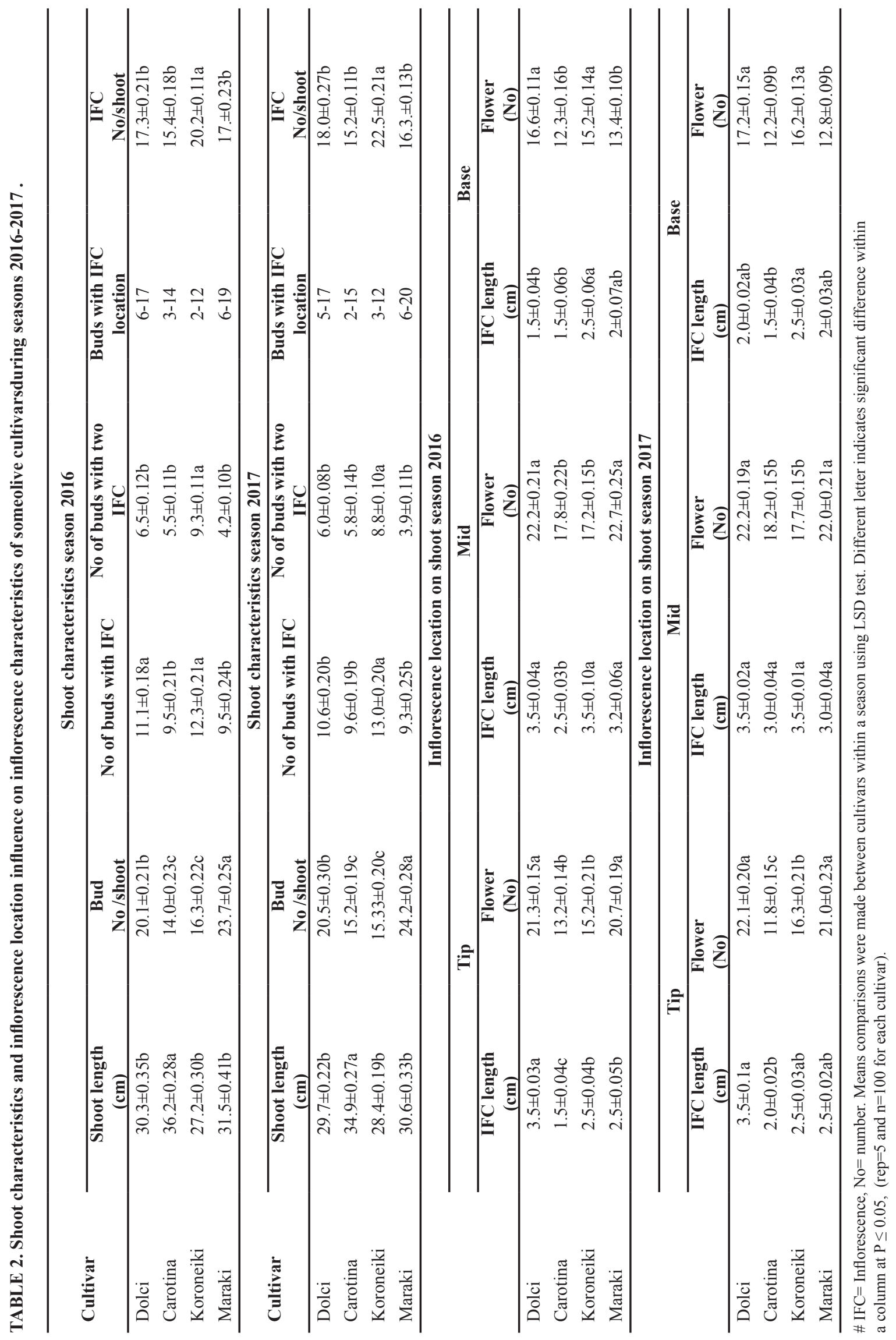

Egypt. J. Hort. Vol. 46, No.1 (2019) 


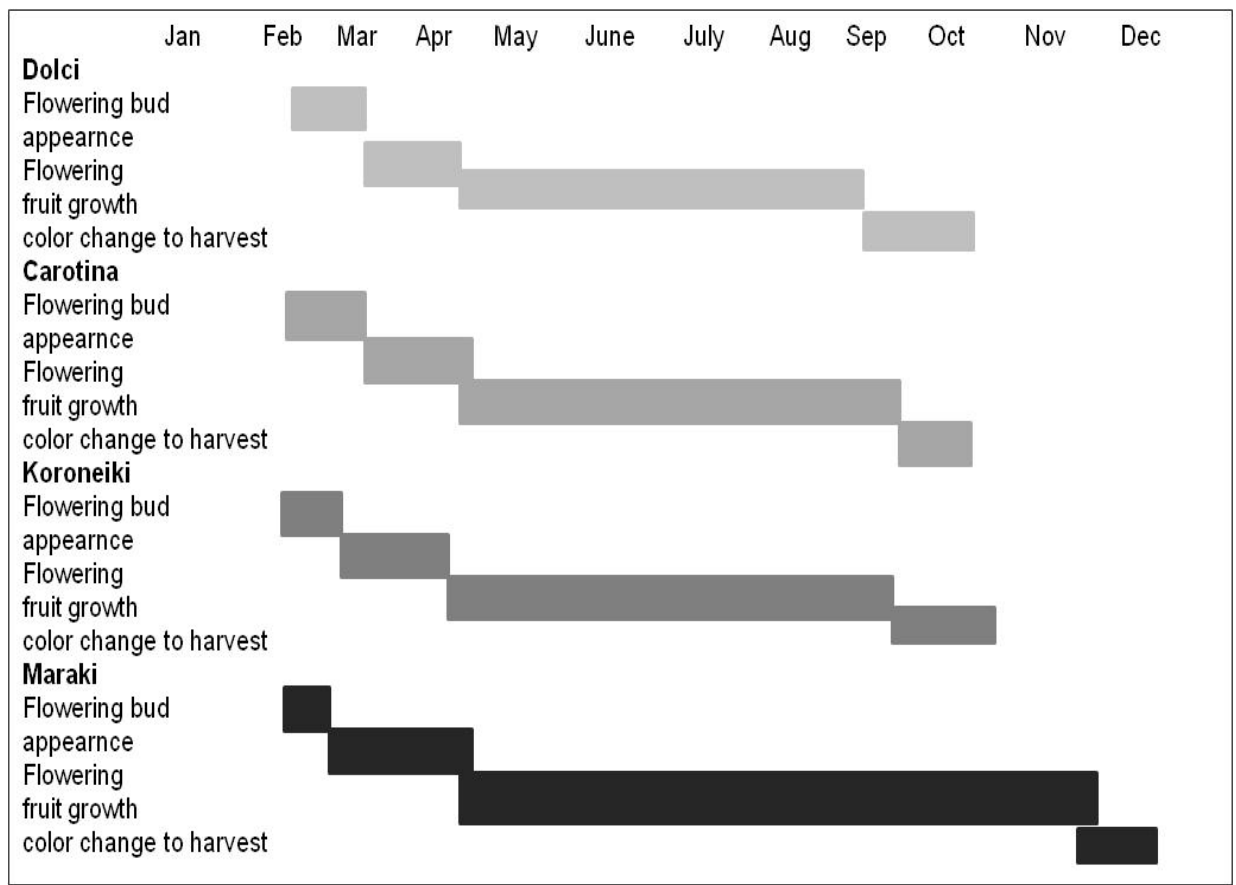

Fig. 1. Flowering and fruiting durations of some olive cultivars during seasons 2016-2017 .

(Lavee et al., 1996). The distribution of the flower buds on the shoot was noticed, as the shoots tended to bear their flower bud on the third bud and along the shoot to the tip in 'Koroneiki' and 'Carotina'cvs., while 'Dolci'and 'Maraki'cvs. shoots bore flower buds on the middle third of the shoot from the six ${ }^{\text {th }}$ bud to $17^{\text {th }}$ and $19^{\text {th }}$ bud, leaving about 4 buds in the tip without any panicle (Fig. 3). The differences in these results may be attributed to the cultivars bearing habit.

Effect of the inflorescence distribution on the shoot (Tip, mid, base) on inflorescence length and flower number per inflorescenceduring 20162017 seasons was obvious (Table 2). In most of the studied cultivars, the middle position of the shoot had the longest panicle contained the highest number of flowers while the shortest panicles with lower number of flower were on the tip and the base, except 'Dolci' cv. as the shoot tip and middle position had panicles with same length and flower number. These results are consistent with previous report that the location of the inflorescence on the shoot had significant effect on the panicle length and the flower number (Seifi et al., 2008)

\section{Inflorescence structure and characteristics}

Inflorescence structures were varied for different olive cultivars during 2016-2017 seasons. There were about 10 different structures observed in this study,and labeled from 1 to 10 (Fig. 2). The main structure noticed in 'Dolci' was (4 and 5) with flowers number $(23,22)$, and'Koroneiki' had structures $(8,9,10)$ with flower number $(20,13$, 11)while the main structures in 'Carotina' were $(6,9,10)$ with flower number $(11,13,11)$. On the other side, several structures were observed in 'Maraki' cultivar and there are structures that were found in all cultivars but in small percent. The inflorescence architecture was found to be wide-ranging from cultivar to another in olive trees as a result of regional condition or tree nutrition statusas reported by Seifi et al. (2008).

Inflorescence length and flower number are varied among shoots, trees, cultivars and seasons (Lavee et al., 1996, Lavee et al., 2002 and Seifi et al., 2011). Data in table 3 showed that 'Maraki' cultivar had the longest panicle with the highest flower number, and'Carotina' cv. had the shortest panicle with less flower number compared to the other cultivars. Despite that,'Koroneiki'cv. has long panicle with the lowest number of the flowers, 'Dolci' cv. has shortest panicle with substantial higher number of the flowers (Fig. $3 \mathrm{~b}$ and Table 3. The lower number of flowersin 'Koroneiki' and 'Carotina'cvs.panicles was due to their structures that have less number of flowers compared to the other structures, (Fig. 2). These results demonstrate that most of olive cultivars could be identified by their inflorescence characteristics. 


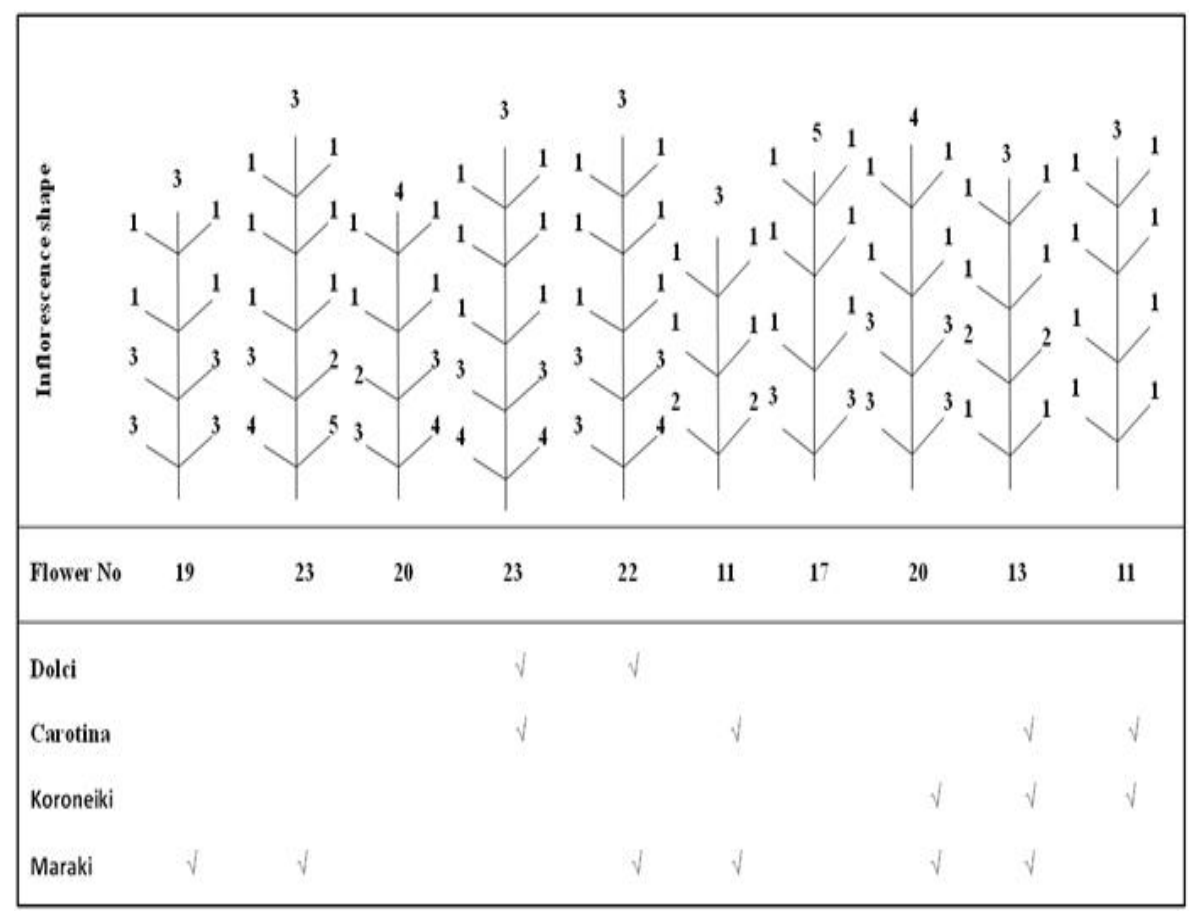

Fig.2 . Inflorescence main structures observed on some oil olive cultivars during seasons 2016-2017.

\section{Fruit set and fruit retention}

Data in Table 3 showed that the perfect flower percentages were quite high in all the studied cultivars and arranged from 79.2 to $88.2 \%$ in both seasons. This high percentage could be important for fruit set and retention and consequently the yield (Lavee et al., 1996). The highest percentage was for 'Maraki' and 'Koroneiki'cvs. followed by 'Dolci', then 'Carotina'cv. that gave the lowest percentage. The highest percentage of initial fruit set $(50.1$ and $52.3 \%)$ was found in 'Carotina', while, the lowest percentage 30.4 and $31.5 \%$ recorded for 'Maraki' in both seasons. The values of'Maraki', 'Dolci' and 'Koroneiki'cvs. were not significant in both seasons. These differences among cultivars may be relatively due to self-incompatibility or the environmental condition such as high temperature, dry wind and less rainfall that affect pollination (Connor and Fereres, 2005, Moutier, 2002).Eassaet al., 2011 reported that the great variations among olive cultivars were existed in the perfect flower percentage and sex ratio related to genetically factors. Initial fruit number/ inflorescence after fruit set was ranged between (5.5-9.2), and initial fruit number/ shoot was between (29.7-38.2) for all cultivars in both seasons, and final fruits number / inflorescencesharply reduced after 20 days to be from 1 to 4.2 and final fruit number / shoot from 2.4 to 34.3 as a result of competition, then stabilized. The drooped fruit number was low in 'Koroneiki' and 'Dolci' while 'Carotina' and

Egypt. J. Hort. Vol. 46, No.1 (2019)
'Maraki' had high drooped fruit number. This may be due to the variation in fruit growth as a result of late fruit set, so only the larger fruit retained and the small fruitsdid not continue growing and fall (Fig. 3a). The competition between fruit begins at bloom and is inversely proportion to the size of flower and fruit (Rosati et al., 2010)

\section{Fruit characteristics}

Fruit characteristics of all studied cultivars during seasons 2016-2017 are presented in Table 3. Despite that 'Maraki' had variability in the fruit size, the average fruit weight was the highest $(5.32 \mathrm{~g})$, 'Dolci' fruit weigh was $(3.06 \mathrm{~g})$ followed by'Carotina' $(2.75 \mathrm{~g})$ and 'Koroneiki' that have the smallest fruit $(0.91 \mathrm{~g})$ in the first season, the same trend was obvious in the second one (Fig. 3 ). These values of fruit weight wasless than that reported in previous reports (Saad El-Din et al., 2010). The decrease in fruit weight may be was a result of the hot weather and dry wind during fruit growth and at harvest that increased water evaporation from the fruit (Fayek et al., 2014, Shaheen et al., 2011,El- Said,et al., 2006). Other fruit characteristics, fruit length and width and stone weight were in turn in the range for the cultivars. Fruit moisture in the olive fruit ranged between (53.2- 67.4\%) in both seasons as presented in Table 3 . These values were more than what reported before about theses cultivars (Saad El-Din et al., 2010). High temperature and low precipitation during fruit ripening resulted in water loss and reduced the moisture contents. 
Such condition may also increase fruit respiration rate and the metabolism rate inside the fruit (AlMaaitah et al., 2009 and Tombesi et al., 1994). On the other side, 'Maraki' cv. fruits had oil content $41.7 \%$ and $40.9 \%$ in both studied seasons which is superior over the other cultivars, as 'Carotina', 'Koroneiki'and 'Dolci'cvs. fruits had 26.4,22.1, $25.7 \%$ oil content in the first season and had $28.2,23.1,26.8$ oil content in the second one (Table 3 ). The growing conditions and the genetic potential of the cultivar had a substantial effect on oil biosynthesis and the final oil content in olive fruits (Al-Maaitah et al., 2009 and Lavee \& Wodne, 2004).

\section{Quality indexes of olive oil}

Oil color: the content of different pigments in olive fruit is important parameter attributed to the quality of olive oil (Gargouri et al., 2013). Chlorophylls in the oil varied among cultivars and ranged between $1.20-2.53 \mathrm{mg} / \mathrm{kg}$ (Table 4). Oil chlorophyll content was the highest in 'Maraki', and the lowest in 'Koroneiki' compared to the other cultivars and control. For all studied cultivars, high content of total chlorophyll was noticed, suggesting that the stage of harvest of the fruit before the other pigments accumulate was the main reason. However, there are also several other factors could affect chlorophyll degradation and causing oxidation reaction in olive oil (Bilancia et al., 2007 and Zegane et al., 2015).

Hydrolytic rancidity and oxidation are the main processes linked with oil deterioration. These processes are usually begins before extracting the oil from the olive fruit, whereas the more oxidation may occur during the extraction process and storage. Some quality indexes indicated the oxidation, the virginity and the purity of olive oil during 2016-2017 seasons are presented in Table 4.

The UV absorption at $\mathrm{K} 232$ and $\mathrm{K} 270$ is a measure of the secondary oxidation products formed in olive oil during the oxidation process (Bilancia et al., 2007). The value of K270 and K232 for the extra virgin oil should be below $0.22,2.50$ respectively, according to IOC. For all cultivars the oil samples were read less than 2.50 for K270 and 0.22 for K232 except for 'Dolci' and 'Carotina' that had slightly higher K270 value $2.92,2.95$ respectively, and the same trend was in the second one (Table 4). This result suggested that there was transformation process of the peroxides in the oil occurredas a response to high temperature during fruit growth (Allouche et al., 2007).

Acidity, on the basis of oleic acid, of all cultivars' oil ranged from $0.20-0.28 \%$ (Table 4 ) in both seasons. These were low values compared to the standard limit for extra virgin olive oil $(0.8 \%)$ suggesting that there were no oil hydrolysis occurred in the fruit on the tree or during the oil extraction (Pereira et al., 2002).

Iodine Value (IV) and Cox Value are the main indicators of the stability and type of oxidation in virgin olive oils (Homapour et al., 2014). The standard range of IV is between 75-94, the studied cultivars' oil IV values were within the range, 86.8 for 'Maraki', 87.7 for 'Koroneiki', however 'Dolci', and 'Carotina' had slightly higher values 89.4- 95.06 compared to the control (88.04). Cox value was higher for all cultivars and ranged between (1.79-2.95) specially 'Dolci', and 'Carotina' compared with previous reports (1.55) (Homapour et al., 2014). These results may be due to the heat stress during fruit growth that hasten oxidation of the lipid by promoting peroxides trasformation (Bruni et al., 1994). The IV and Cox values indicated that the oil of 'Maraki' and 'Koroneiki' cv. showed stability and resistance against oxidation, while 'Dolci' and 'Carotina' cvs. showed less stability against oxidation suggestion that the oil polyunsaturated fatty acid content may be the reason (Table 4).

Phenolics are natural antioxidants present in virgin olive oil and linked to the shelf life stability (Ouni et al., 2012). These compounds are susceptible to heat stress, and will degrade into other compounds if exposed to heat for long periods of time (Gallina-Toschi et al., 2005, Lee et al., 2007). Our results showed that the content of total phenols in most of the studied cultivars was high (479.6- 361.3) except for the 'Dolci' that had lower content $332.3 \mathrm{mg} / \mathrm{kg}$ (Table 4 ).

High contents of Phenolicsin these cultivars' increased the stability against oxidation and extend the shelf life (Ahmed \& Taha, 2018, HaghighatKharazi et al., 2012 and Ryan et al., 1998).Fatty acid profile for all cultivars' oil during seasons 2016-2017 was described in Table 5. Oleic acid content was the highest in 'Maraki' $71.85 \%$ while the palmitic acid content was highest in 'Dolci' compared to other cultivars. The ratio of oleic to linoleic acid was ranged between 2.99$7.83 \%$. 'Maraki' oil has the highest ratio among all cultivars consistant with the prevouis report (Hashempour et al., 2010). In general, the ratio of saturated to unsaturated fatty acids was lower in 'Maraki' and 'Koroneiki' compared to the other cultivars suggesting that the maturity of the fruit influenced olive oil's fatty acids profile (Cimato, 1990). It is also reported that, as the environmental temperature increase, the unsaturated fatty acid content decreases, while when the temperature decrease the saturated fatty acid contents increase (Ahmed and Taha, 2018, Kiralan et al., 2009 and Rondanini et al., 2011). 


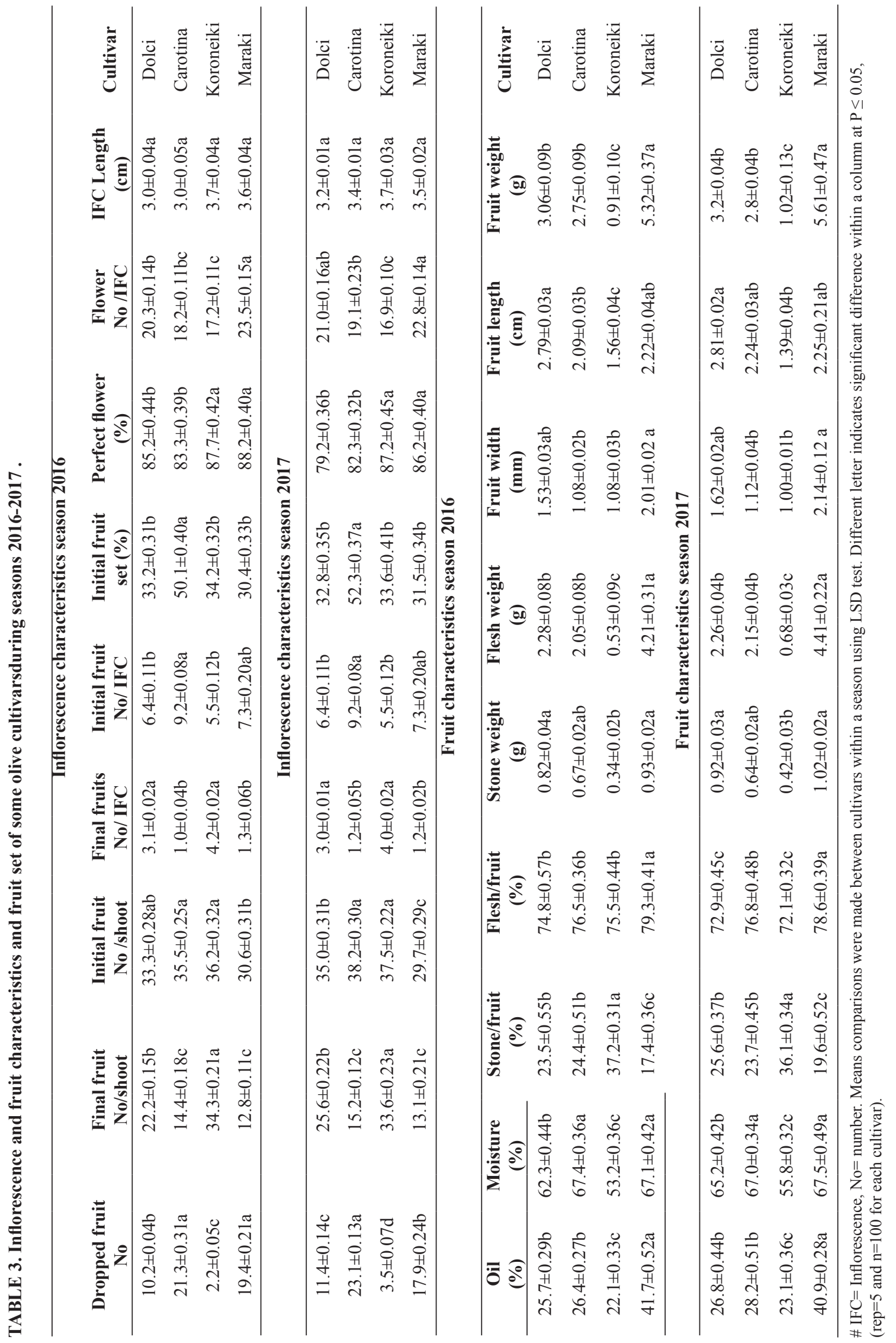

Egypt. J. Hort. Vol. 46, No.1 (2019) 


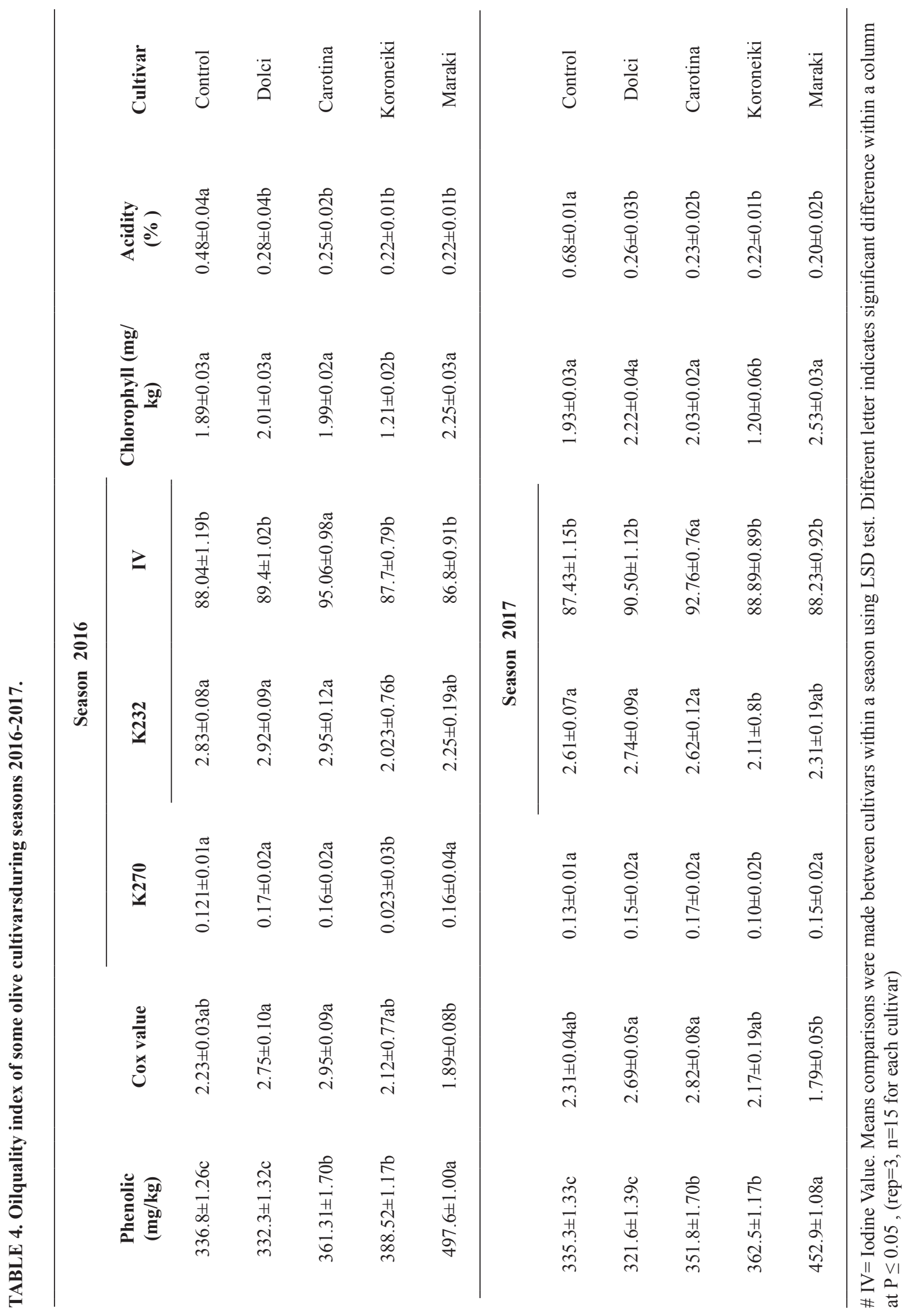

Egypt. J. Hort. Vol. 46, No.1 (2019) 


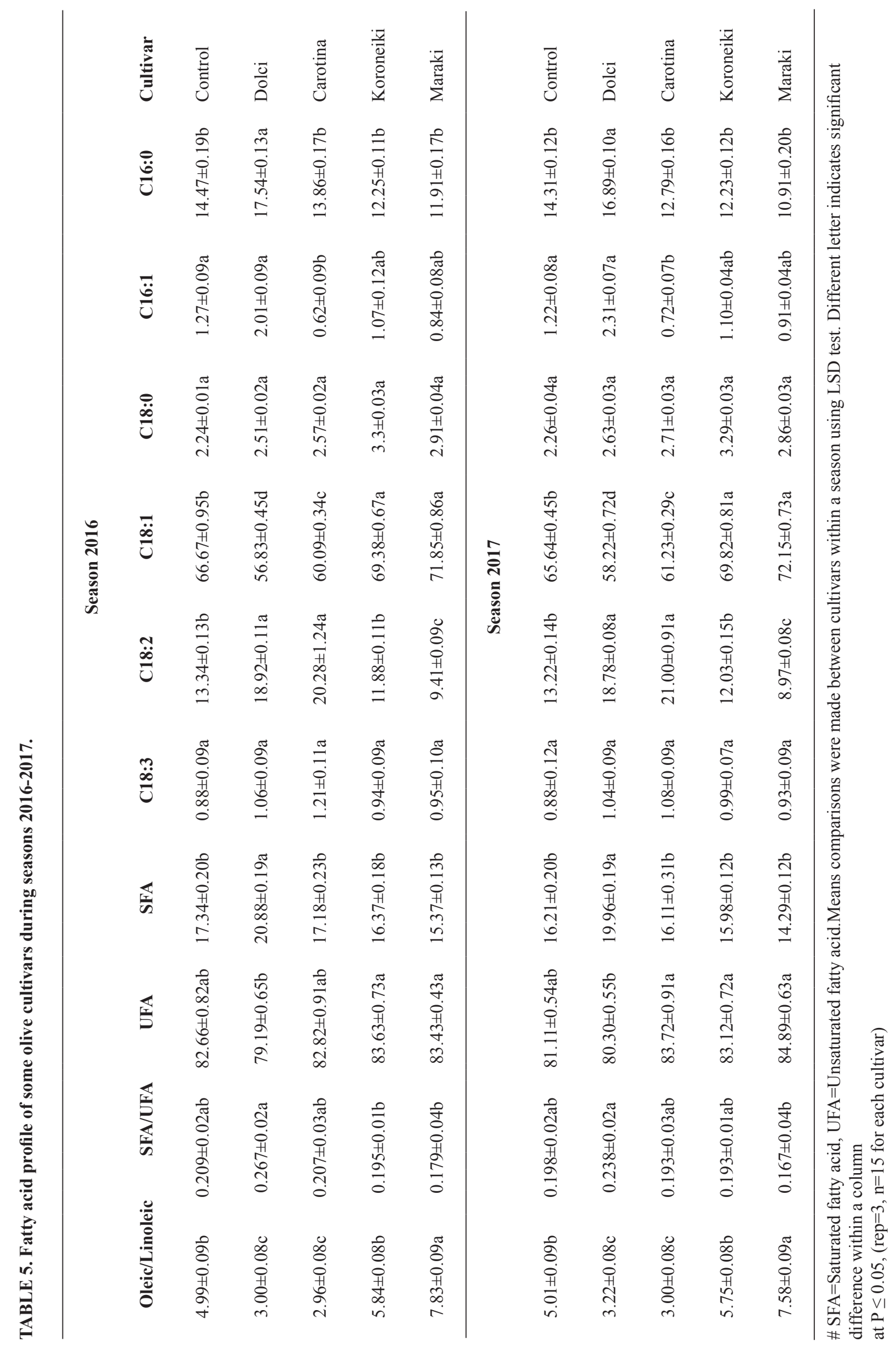

Egypt. J. Hort. Vol. 46, No.1 (2019) 


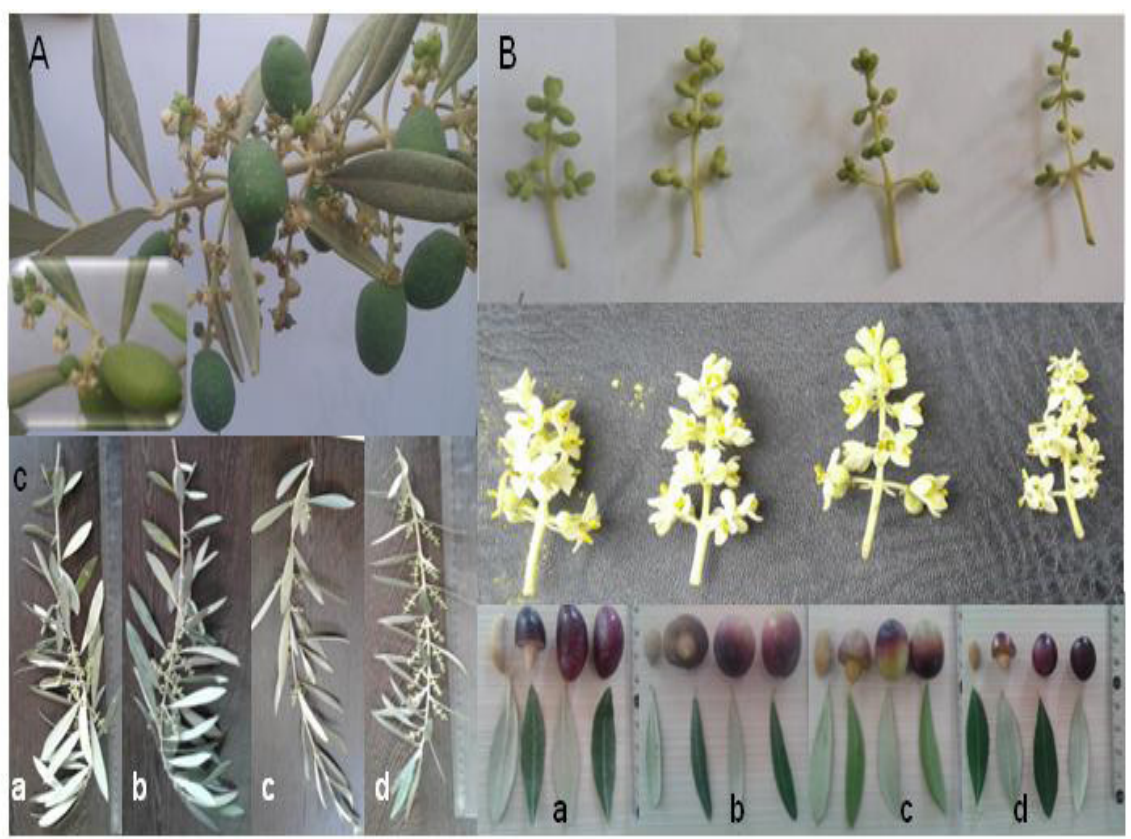

Fig. 3. Flowering, fruiting in four olive cultivars: a- 'Dolci', b- 'Maraki', c- 'Carotina' d- 'Koroneiki'. A) 'Maraki' cultivar'sfruit growth variation. B) Inflorescence, fruit, seed C) One year old shoot

\section{Conclusion}

The present study results provide evidence that the studied olive cultivarswere successfully grew and hada capability to adapt the condition of southern Egypt. The cultivars hadusual morphological characteristics, fruit production and oil quality. 'Maraki' and 'Koroneiki' cultivars prove tolerance to the hot and dry summer by maintaining the oil stability against oxidation and best high valued oil compared to 'Dolci' and 'Carotina' suggesting that 'Maraki' and 'Koroneiki' can successfully grow and give high quality extra virgin olive oil under southern region conditions.

\section{Acknowledgments:}

The authors are thoughtful to South Valley University, College of Agricultural, Qena, Egypt for the financial support of this project. A great thankful also goes to the Agriculture research center, Food Technology Research Institute, Oils and Fats Research Department, Egypt, for providing the oil fatty acid profile analysis.

\section{Funding statements:}

This research is funded by College of Agriculture, South Valley University, Qena, Egypt.

\section{Conflict of interest:}

The authors have declared that there is no conflict of interest.

\section{References}

Ahmed, Z.F.R. and Taha, E. M. (2018) Fruit characteristics and olive oil quality in response to some environmental factors. ActaHort., 1216, 19-26.

A.O.A.C. (2000) Offecial Methods of Analysis, Association of offecial analytical chemists, $5^{\text {th }}$ ed., Arlington, Virginia, USA.

Al-Maaitah, M.I., Al-Absi, K.M., and Rawashdeh, A.A. (2009) Oil quality and quantity of three olive cultivars as influenced by harvesting date in the middle and southern parts of Jordan. Int .J. Agric. Biol., 11, 266-272.

Allouche, Y., Jimenez, A., Gaforio, J.J., Uceda, M., and Beltran, G. (2007) How heating affects extra virgin olive oil quality indexes and chemical composition.J. Agric. Food Chem., 55, 9646-9654.

Bertrand, E. (2002) The beneficial cardiovascular effects of the Mediterranean diet Olivae, 90, 29-31.

Bilancia, M.T., Caponio, F., Sikorskab, E., Pasqualonea, A., and Summo, C. (2007) Correlation of triacylglycerol oligopolymers and oxidised triacylglycerols to quality parameters in extra virgin olive oil during storage. Food Res. Inter.,40, 855-861.

Egypt. J. Hort. Vol. 46, No.1 (2019) 
Bruni, U., Cortesi, N., and Fiorino, P. (1994) Influence of agricultural technigues, cultivar and area of origin on characteristics of virgin olive oil and on levels of some of its minor components. Olivae, $\mathbf{5 3}$, 28-34.

Christie, W.W. (1982) Lipid Analysis (2nd edn). Pergamon, Oxford.

Cimato, A. (1990) Effect of agronomic factors on virgin olive oil quality. Olivae, 31, 20-31.

Connor, D.J., and Fereres, E. (2005) The physiology of adaptation and yield expression in olive.Hortic. Rev., 31, 155-229.

Di Vaio, C., Nocerino, S., Paduanob, A., and Sacchib, R. (2012) Influence of some environmental factors on drupe maturation and olive oil composition. $J$. Sci. Food Agric., 93, 1134-1139.

Eassa, K.B.,El-Taweel, A.A. and Gowda,A. M. (2011) Studies on self and cross pollination on the productivity and quality of Kalamata olive trees grown in sandy soils. J. Agric. Res. Kafer ElSheikh, 37, 127-140.

El- Said, M.E., Gowda, A.M. and Hassan, M.A. (2006) Studies on some olive cultivars under Beni- Suef Governorate conditions..Alex. J. Agric. Res., 51, $137-151$.

Fabbri, A., and Benelli, C. (2000) Review Article Flower bud induction and differentiation in olive. J. Hort. Sci.Biotechnol., 75, 131-141.

Fayek, M.A., Abdel-Mohsen, M.A., Laz, S.I., and ElSayed,.M. E. (2014) Morphological, Agronomical and Genetic Characterization of Egyptian Olive Clones Compared with the International Cultivars. Egypt. J.Hort ., 41, 59- 82.

Gallina-Toschi, T., Cerretani, L., Bendini, A., BonoliCarbognin, M., and Lercker, G. (2005) Oxidative stability and phenolic content of virgin olive oil: An analytical approach by traditionaland high resolution techniques. J. Sep. Sci.,28, 859-870.

Gargouri, B., Ammar, S., Zribi, A., Ben Mansour, A., and Bouaziz, M. (2013) Effect of growing region on quality characteristics and phenolic compounds of chemlali extra-virgin olive oils. Acta Physiol. Plant,35, 2801-2812.

Haghighat-Kharazi, S., Esmaeilzadeh Kenari, R., Raftani Amiri, Z., and Azizkhani, M. (2012) Characterization of Iranian virgin olive oil from the Roodbar region: A study on Zard, Mari and Phishomi. J. Amer. Oil Chem. Soc., 89, 1241-1247.

Egypt. J. Hort. Vol. 46, No.1 (2019)
Hashempour, M., Fotouhi Ghazvini, R., Bakhshi, D., Aliakbar, A., Papachatzis, A., and Kalorizou, H. (2010) Characterization of virgin olive oils (Olea europaea L.) from three main Iranian cultivars, 'Zard', 'Roghani' and 'Mari' in Kazeroon Region Biotechnol.Biotec. Eq., 24, 2080-2084.

Homapour, M., Ghavami, M., Piravi-Vanak, Z., and Hosseini, S.E. (2014) Chemical properties of virgin olive oil from Iranian cultivars grown in the Fadak and Gilvan regions. Grasas Aceites.,65, 43-52.

I.O.C (2013) International olive council, trade standard applying to olive oils and olive-pomace oil. COI/T.15/NC No 3/Rev. 7.

Kiralan, M., Bayrak, A., and Mucahit, T.O. (2009) Oxidation stability of virgin olive oils from some important cultivars in East Mediterranean area in Turkey. J. Amer. Oil Chem Soc., 86, 247-252.

Lavee, S., Rallo, L., Rapoport, H.F., and Troncoso, A. (1996) The floral biology of the olive: Effect of flower number, type and distribution on fruit set. Scientia Hort., 66, 149-158.

Lavee, S., Taryan, J., Levin, J., and Haskal, A. (2002) The significance of cross-pollination for various olive cultivars under irrigated intensive growing conditions. Olivae, 91, 25-36.

Lavee, S., and Wodne, M. (2004) The effect of yield, harvest time and fruit size on the oil content in fruits of irrigated olive trees (Olea europea), cvs. Barnea and Manzanillo. Scientia. Hort., 99, 267-277.

Lee, J., Lee, Y., and Choe, E. (2007) Temperature dependence of the autoxidation and antioxidants of soybean, sunflower, and olive oil. Europ. Food. Res. Technol., 226, 239-246.

Lombardo, N., Marone, E., Alessandrino, M., Giodino, G., Madeo, A., and Fiorino, P. (2008) Influence of growing season temperatures on the fatty acids (FAs) of triacylglycerols (TAGs) composition in Italian cultivars of Olea europaea.Adv.Hort.Sci.,22, 49-53.

Martin, G.C., Ferguson, L., and Sibbett, G.S.M. (2005) Flowering, pollination, fruiting, alternate bearing, and abscission', p. 49-54. In: Sibbett, G.S., Ferguson, L., Coviello, J.L., and Lindstrand, M. (Eds.). Olive Production Manual. University of California, Agriculture and Natural Resources, Oakland, California.

Mookerjee, S., Guerin, J., Collins, G., Ford, C., and Sedgley, M. (2005) Paternity analysis using microsatellite markers to identify pollen donors in 
an olive grove. Theor. Appl. Genet.,111, 1174-1182.

Moutier, N. (2002) Self-fertility and intercompatibilities of sixteen olive varieties. Acta Hort., 586, 209-212.

Orlandi, F., Vazquez, L.M., Ruga, L., Bonofiglio, T., Fornaciari, M., Garciamozo, H., Dominguez, E., Romano, B., and Galan, C. (2005) Bioclimatic requirements for olive flowering in two Mediterranean region located at the same latitude (Andalucia,Spain and Sicily, Italy. Ann. Agric. Environ., 12, 47-52.

Ouni, Y., Taamali, A., Guerfel, M., Abdellly, C., Zarrouk, M., and Flamini, G. (2012) The phenolic compounds and compositional quality of Chetoui virgin olive oil: Effect of altitude. African $J$. Biotech., 11, 11842-11850.

Pannelli, G., Servili, M., Servaggini, R., Baldioli, M., and Montedoro, G.F. (1994) Effect of agronomic and seasonal factors on olive (Olea europaea L.) production and on the qualitative characterization of the oil. Acta Hort., 356, 239-244.

Pereira, J.A., Casal, S., Bento, A., and Oliveira, M. (2002) Influence of olive storage period on oil quality of three Portuguese cultivars of Olea europea, Cobrangosa, Madural, and Verdeal Transmontana. J. Agri. Food Chem.,50, 6335-6340.

Pérez López, D., Ribas, F., Moriana, A., Rapoport, H., and De Juan, A. (2008) Influence of temperature on the growth and development of olive (Olea europaea L.). J. Hort. Sci. Biotechnol., 83, 171-176.

Rondanini, D.P., Castro, D.N., Searles, P.S., and Rousseaux, M.C. (2011) Fatty acid profiles of varietal virgin olive oils (Olea europaea L.) from mature orchards in warm arid valleys of Northwestern Argentina (La Rioja). Grasas Aceites, 62, 399-409.

Rosati, A., Zipancic, M., Caporali, S., and Paoletti, A. (2010) Fruit set is inversely related to flower and fruit weight in olive (Olea europaea L.). Scientia Hort., 126, 200-204.

Ryan, D., Robards, K., and Lavee, S. (1998) Evaluation de la qualité de l'huile d'olive. Olivae,75, 31-36.
Saad El-Din, I., Shaheen, A.S., and El-Bolok, T.K. (2010) Evaluation of some olive cultivars grown under Sohag governorate conditions. Egypt. J. Hort., 37, 235-256

SAS ${ }^{\circledR}$, I.I. (2009) SAS Online Doc. Version 9. 2 Copyright 2009. SAS Institute Inc, Cary, NC, USA

Seifi, E., Guerin, J., Kaiser, B., and Sedgley, M. (2008) Inflorescence architecture of olive. Scientia Hort., 116, 273-279.

Seifi, E., Guerin, J., Kaiser, B., and Sedgley, M. (2011) Sexual compatibility and floral biology of some olive cultivars. New Zealand J. Crop Hort. Sci., 39, 141-151

Shaheen, A.S., El - Taweel, A.A., and Al-Khateeb, A. (2011) Effect of Using Olive Vegetation Water (OVW) on Growth, Flowering and Yield of Manzanillo Olive Trees. J. Amer. Sci.,7, 501-508.

Tognetti, R., D’Andria, R., Sacchi, R., Lavini, A., Morelli, G., and Alvino, A. (2007) Deficit irrigation affects seasonal changes in leaf physiology and oil quality of Olea europaea (cultivars Frantoio and Leccino). Ann. Appl. Biol., 150, 169-186j

Tombesi, A., Pilli, M., Boco, M., and Proietti, P. (1994) Evolution of olive fruit respiration, photosynthesis and oil composition during ripening. Acta Hort., 356, 420-445.

Tous, J., and Romero, A. (1994) Cultivar and location effects on olive oil quality in Catalonia, Spain. Acta Hort., 356, 323-326.

Weiying, X., Mingquanand, D., and Ning, Y. (1998) Studio delle regioni cineci all oliviculture. Olivae, 70, 19-31.

Zegane, O., Keciri, S., and Louaileche, H. (2015) Physicochemical characteristics and pigment content of algerian olive oils: effect of olive cultivar and geographical origin. Inter. J. Chemi. Biomole. Sci., 1, 153-157.

(Received 24/03/2019, accepted 09/05/2019) 


\section{السلوك الزهرى وخصائص الثمار وجودة الزيت لبعض اصناف الزيتون

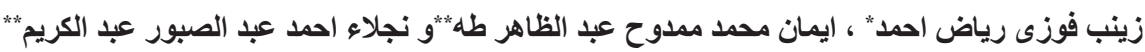

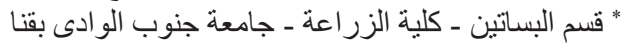

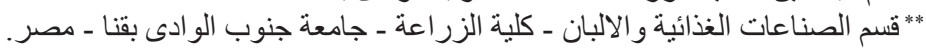

لقد زاد الطلب على استهلاك الزيتون حول العالم لما لثماره وزيته من خصائص علاجية عالية. ومواجهة هذا

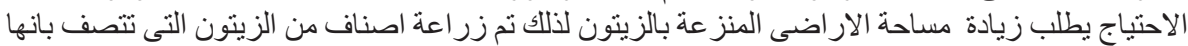

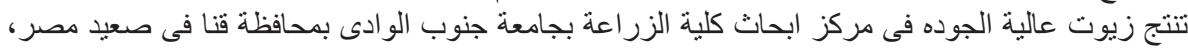

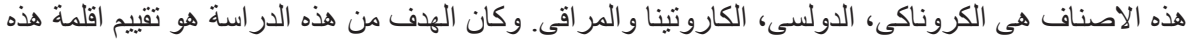

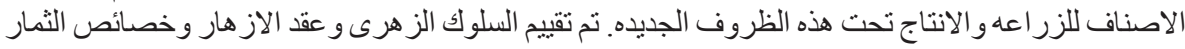

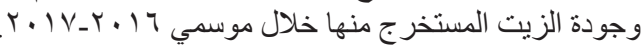

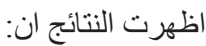

بداية موسم النمو فى هذه المنطقه كانت فى اول فبر اير عند ظهور البراعم الزهرية اي بحو الى اسبو عين

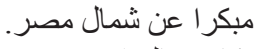

كان هناك اختلاف معنوى للسلوك الزهرى حيث كان عدد العناقيد الزهريه اكثر فى صنف الكروناكى

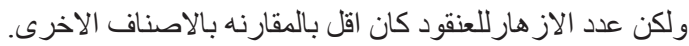

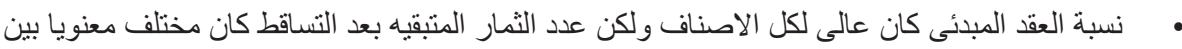

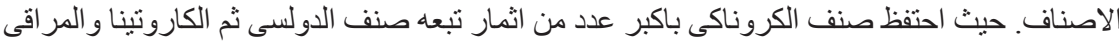
الذى اشجل اعلى نسبة تساقط للثمار. • جم ووزن الثمار كان اقل قليلا من القيم التى عرضت فى الابحاث السابقه لهذه الاصناف فى مناطق • المر اقى اعطى اعلى نسبة من الزيت يليه الكاروتينا ثم الدولسى و الكروناكى.

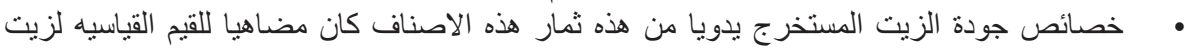

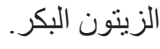

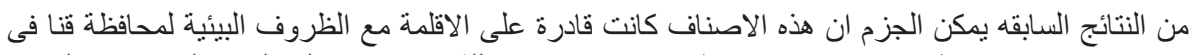

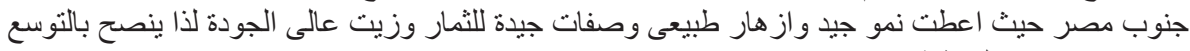
بزر اعتها فى هذه المنطقة. 